\title{
Psychological Characteristics and Non-farm Livelihood Options of Rural Youth in Jabalpur District of Madhya Pradesh India
}

\author{
Victor Chibuzor Umunnakwe* \\ Department of Extension Education and Rural Management, Jawaharlal Nehru Agricultural University Jabalpur 482004 (MP), India \\ *Corresponding author: chivicumunna@yahoo.com
}

Received August 07, 2014; Revised August 16, 2014; Accepted September 03, 2014

\begin{abstract}
Many rural youth are faced with difficulty of maintaining livelihoods and consequently, poverty remains pervasive among them. The importance of income generating activities to rural livelihood cannot be overemphasized. The paper examined the involvement of rural youth in non-farm income generating activities and their psychological characteristics as well as the relationship between their psychological characteristics and their involvement in non-farm income generating activities. Multi-stage random sampling was used to collect data from 247 respondents through interview schedule and data was categorized with mean and standard deviation while Pearson Product Moment Correction (PPMC) was used to test relationships. The results revealed that majority of the respondents had medium risk orientation, economic motivation and innovativeness while first degree and business were the aspired educational attainment and occupation by majority respectively. The findings also showed that majority of rural youth were conservative and fatalistic. Petty trading and pottery were the most and least ranked income generating activities participated by the respondents. Achievement motivation $(\mathrm{r}=0.455, \mathrm{P}<0.01)$, risk orientation $(r=0.364, \mathrm{P}<0.01)$, economic motivation $(r=0.446, \mathrm{P}<0.01)$ and innovativeness $(\mathrm{r}=0.345, \mathrm{P}<0.01)$ had a significant positive relationships with involvement in non-farm income generating activities whereas educational aspiration $(\mathrm{r}=-0.222$, $\mathrm{P}<0.01)$, occupational aspiration $(\mathrm{r}=-0.133$, $\mathrm{P}<0.05)$, conservatism-liberalism $(\mathrm{r}=-0.407, \mathrm{P}<0.01)$ and fatalism-scienticism $(\mathrm{r}=-0.327, \mathrm{P}<0.01)$ had significant and negative relationships with involvement in non-farm income generating activities. Governmental and non-governmental organizations should take into consideration all non-farm income generating activities engaged in by rural youth as well as the above psychological variables when initiating and embarking on programmes targeted at improving their livelihoods.
\end{abstract}

Keywords: psychological, relationship, livelihoods, income generating activities, rural, youth

Cite This Article: Victor Chibuzor Umunnakwe, "Psychological Characteristics and Non-farm Livelihood Options of Rural Youth in Jabalpur District of Madhya Pradesh India.” American Journal of Rural Development, vol. 2, no. 3 (2014): 53-58. doi: 10.12691/ajrd-2-3-3.

\section{Introduction}

Rapid population growth which brought about reduction of cultivable land, erosion, loss of soil fertility and biodiversity has resulted in a decreasing agricultural productivity and negative effect on people's income as well as accelerated rural poverty [1]. According to [2], poverty remains predominantly a rural phenomenon despite rapid urbanization observed in most developing and transition countries.

There are over one billion youth (aged 15-24) in the world, 85 percent of these youth live in the developing countries and about 50 percent of youth population in developing countries live in rural areas [3]. They constitute a reasonable force propelling rural economy, nonetheless, poverty is still pervasive among rural youth who face numerous challenges in order to achieve and maintain their livelihoods. [4], reported that youth globally have difficulties in accessing livelihood opportunities. In societies governed by principles of age and where control of resources is in the hands of older people, young people have little opportunities to express their interests and needs. This explains why youth issues have not received much needed attention in development policies. Despite the fact that globally, the burning problems on the present day relates to rural youth, not much have been done to collect information about them in many countries and knowledge about their livelihoods remained fragmented among service providers [5].

Rural households world-wide engage in a variety of non-farm activities to generate income $[6,7,8]$.The contribution of non-farm income to rural income shares cannot be underestimated. For Latin America and Caribbean, estimates of rural non-farm income shares for rural households were 22\% in Honduras, 59\% in Costa Rica and 68\% in Haiti [9]. Recent data for Eastern Europe indicated 31\% in Armenia and 68\% in Bulgaria [10,11], found that intensive farming with increased mechanization of agriculture has led to a fall in farm employment in India. 
In another report by [12] land based livelihoods of small and marginal farmers are increasingly becoming unsustainable in India, since their land has not been able to support their family's food requirement and fodder for their cattle. According to [13], low level of production and entrepreneurship as well as decreasing involvement of youth in agriculture brought about low level of agricultural skills and limited access to financial resources. Consequently, rural households are forced to look at alternative non-agricultural income generating activities for their survival. [14], reported that the rural poor engage in non-farm activities, both as a compliment to their farm activities and as a substitute for their farm incomes. Concomitantly, there has been increasing involvement of youth in rural non-farm income generating activities like craft work, trade and employment in both unorganized and organized non-agricultural private sectors [15].

Living standard of the rural poor would only be uplifted when they receive income from economic activities $[16,17,18]$. Therefore the study aims at determining the interplay between psychological characteristics of rural youth and their involvement in non-farm income generating livelihood activities. Undoubtedly, the outcome of this study will be instrumental in developing policies and services aimed at reducing rural poverty.

\section{Methodology}

\subsection{Description of the Study Area}

Jabalpur is located on $23^{\circ} 10^{\prime} \mathrm{N}$ latitude and $79^{\circ} 57^{\prime} \mathrm{E}$ longitude. According to the 2011 census, Jabalpur district has a population of 2,460,714 people. The area of the district is $10,160 \mathrm{Km} 2$ while the administrative headquarters is located at Jabalpur city [19].

\subsection{Sampling Procedure and Sample Size}

Multi-stage and simple random sampling were used to compose the sample. In the first stage, two (Panagar and Patan) out of the six blocks in the district were randomly selected. The second stage involved delineation of the rural villages in the two blocks selected. Five rural villages were randomly selected from each of the two blocks (Panagar and Patan) making the total rural villages selected to be ten. Twenty percent of total households in the ten rural villages were selected and one youth from each household was interviewed bringing the sample size to two hundred and forty seven (247).

Table 1. Villages and rural youth sampled in the study area

\begin{tabular}{|c|c|c|c|c|}
\hline S.No. & Villages & Total households & $\begin{array}{c}\mathbf{2 0 \%} \text { of total } \\
\text { households }\end{array}$ & $\begin{array}{c}\text { No. of youth } \\
\text { selected }\end{array}$ \\
\hline 1. & Belkhadu & 13 & 3 & 3 \\
\hline 2. & Padariya & 381 & 76 & 76 \\
\hline 3. & Pipariya & 87 & 17 & 17 \\
\hline 4. & Pondi & 67 & 13 & 13 \\
\hline 5. & Umaliya & 115 & 23 & 23 \\
\hline 6. & Benikheda & 223 & 45 & 45 \\
\hline 7. & Doni & 60 & 12 & 12 \\
\hline 8. & Luhari & 89 & 18 & 18 \\
\hline 9. & Nimi & 44 & 9 & 9 \\
\hline 10. & Timri & 157 & 31 & 31 \\
\hline & Total & $\mathbf{1 2 3 6}$ & $\mathbf{2 4 7}$ & $\mathbf{2 4 7}$ \\
\hline
\end{tabular}

\subsection{Method of Data Collection}

Deriving accurate information is highly dependent upon the survey method [20]. According to [21], the most commonly used approach is the direct face-to-face interview. In this study, interview schedule was used to collect data on psychological characteristics as well as non-farm income generating activities.

\subsection{Measurement of Variables}

According to Sheheli [1], when different dimensions of the livelihood issue are considered, the incidence of income is the most important. Living standard of the rural poor would only be uplifted when they receive income from the economic activities $[16,17,18]$. Income generating activities change the livelihood of the poor in terms of living condition, housing, nutrition, savings, dress, medical treatment, health, sanitation, liberalization and education [22]. The dependent variable for the study which is involvement in non-farm income generating activities was measured using a 3 point likert type scale of fully involved, partially involved and not involved (2, 1, $0)$. Achievement motivation, risk orientation and economic motivation were measured using Likert's 5 point attitudinal scale of strongly agree, agree, undecided, disagree and strongly disagree $(5,4,3,2,1)$ for positive statements while the scores were reversed for negative statements. Interrogative statements were used to capture innovativeness (yes $=2 \&$ No $=1$ ). Also respondents were asked to indicate only one educational attainment (No educational aspiration $=0,10^{\text {th }}$ standard $=1,12^{\text {th }}$ standard $=2$, First degree $=3$ Master's degree $=4, \mathrm{PhD}$ and above $=5$ ) as well as occupation ( Farming $=1$, Factory work = 2, Office work $=3$ and Business $=4$ ) they aspire. Conservatism-liberalism and fatalism-scienticism were equally measured with Likert's 5 point attitudinal scale of strongly agree, agree, undecided, disagree and strongly disagree $(5,4,3,2,1)$ for statements that suggested conservatism and fatalism whereas the opposite applied for statements that suggested liberalism and scienticism. The cumulative scores obtained for all variables except educational and occupational aspiration were categorized as low, medium and high using the formulae:

Low $<(X-0.425 S D)$

Medium (X \pm 0.425 SD)

High $>(X+0.425$ SD)

Where $\mathrm{X}=$ Mean of the cumulative score

$\mathrm{SD}=$ Standard Deviation of the cumulative score.

Conservative-liberalism as well as fatalism-scienticism was dichotomized using only the mean of their cumulative scores. Relationship between psychological characteristics and involvement in non-farm income generating activities was tested with Pearson Product Moment Correlation (PPMC). Inter-correlation between psychology characteristics was also tested using PPMC.

\section{Results and Discussion}

Though majority (35.63\%) of the respondents had low achievement motivation, almost equal percentage of them also had high achievement motivation (Table 2). Majority of rural youth had medium risk orientation (53.04\%), economic motivation (49.80\%) and innovativeness (42.11\%). 
In related findings, [23] and [24] concluded that majority of women entrepreneurs had medium risk orientation. It is also evident from Table 2 that majority of the respondents aspired for first degree education (19.60\%) and business occupation (46.20\%) respectively. [25] in their study confirmed that majority of non school going rural youth indicated business as their preferred occupation. Higher proportions of the respondents were conservatives (59.11\%) and fatalistic (56.28\%).

Table 2. Frequency distribution and categorization of respondents' psychological characteristics

\begin{tabular}{|c|c|c|}
\hline Variables & Frequencies & Percentages \\
\hline \multicolumn{3}{|c|}{ Achievement motivation $($ Mean $=12.60$, SD $=2.424$ ) } \\
\hline Low $<(\mathrm{X}-0.425 \mathrm{SD})$ & 88 & 35.63 \\
\hline Medium $(\mathrm{X} \pm 0.425 \mathrm{SD})$ & 74 & 29.96 \\
\hline High $>(\mathrm{X}+0.425 \mathrm{SD})$ & 85 & 34.41 \\
\hline Total & 247 & 100.00 \\
\hline \multicolumn{3}{|c|}{ Risk orientation ( Mean $=28.43$, SD $=5.021$ ) } \\
\hline Low < $(\mathrm{X}-0.425 \mathrm{SD})$ & 76 & 30.77 \\
\hline Medium $(\mathrm{X} \pm 0.425 S \mathrm{~S})$ & 131 & 53.04 \\
\hline High $>(X+0.425 S D)$ & 40 & 16.19 \\
\hline Total & 247 & 100.00 \\
\hline \multicolumn{3}{|c|}{ Economic motivation ( Mean $=30.43, \mathrm{SD}=5.939$ ) } \\
\hline Low < $(\mathrm{X}-0.425 \mathrm{SD})$ & 52 & 21.05 \\
\hline Medium $(\mathrm{X} \pm 0.425 \mathrm{SD})$ & 123 & 49.80 \\
\hline High $>(X+0.425 S D)$ & 72 & 29.15 \\
\hline Total & 247 & 100.00 \\
\hline \multicolumn{3}{|c|}{ Innovativeness $($ Mean $=8.63, \mathrm{SD}=1.692$ ) } \\
\hline Low < $(\mathrm{X}-0.425 \mathrm{SD})$ & 57 & 23.08 \\
\hline Medium $(\mathrm{X} \pm 0.425 \mathrm{SD})$ & 104 & 42.11 \\
\hline High $>(X+0.425 S D)$ & 86 & 34.81 \\
\hline Total & 247 & 100.00 \\
\hline \multicolumn{3}{|l|}{ Educational aspiration } \\
\hline No educational aspiration & 131 & 53.00 \\
\hline $10^{\text {th }}$ standard & 8 & 3.20 \\
\hline $12^{\text {th }}$ standard & 16 & 6.50 \\
\hline First degree & 48 & 19.60 \\
\hline Master's degree & 36 & 14.60 \\
\hline PhD and above & 8 & 3.20 \\
\hline Total & 247 & 100.00 \\
\hline \multicolumn{3}{|l|}{ Occupational aspiration } \\
\hline Farming & 65 & 26.30 \\
\hline Factory work & 16 & 6.50 \\
\hline Office work & 52 & 21.10 \\
\hline Business & 114 & 46.20 \\
\hline Total & 247 & 100.00 \\
\hline \multicolumn{3}{|c|}{ Conservatism-liberalism (Mean=19.62, SD=4.142) } \\
\hline Conservatism (Above mean score) & 146 & 59.11 \\
\hline Liberalism (Below mean score) & 101 & 40.89 \\
\hline \multicolumn{3}{|c|}{ Fatalism-scienticism $($ Mean $=14.28, \mathrm{SD}=4.189)$} \\
\hline Fatalism (Above mean score) & 139 & 56.28 \\
\hline Scienticism (Below mean score) & 108 & 43.72 \\
\hline Total & 247 & 100.00 \\
\hline
\end{tabular}

In Table 3, the most participated non-farm income generating activities were petty trading (ranked first), hired labour (ranked second) and construction work that ranked third. Similar result was reported by [26] and [27] that trading was the most participated non-farm income generating activities among farmers and rural dwellers respectively. These findings support the views of [28]; [29]; [26]; [1] and [30] that even though farming is the predominant activity in most rural areas, rural dwellers usually engage in non-farm income generating activities.

Table 3. Ranking by mean the extent of involvement in non- farm income generating activities

\begin{tabular}{|c|l|c|c|}
\hline S.No. & Non-agricultural income generating activities & Mean & Rank \\
\hline 1. & Petty trading & 0.78 & $1^{\text {st }}$ \\
\hline 2. & Blacksmith & 0.16 & $9^{\text {th }}$ \\
\hline 3. & Craft work & 0.06 & $14^{\text {th }}$ \\
\hline 4. & Carpentry & 0.11 & $11^{\text {th }}$ \\
\hline 5. & Pottery & 0.00 & $17^{\text {th }}$ \\
\hline 6. & Shoe repair/Shoe shining & 0.03 & $16^{\text {th }}$ \\
\hline 7. & Barbing & 0.11 & $11^{\text {th }}$ \\
\hline 8. & Motorcycle/bicycle repair & 0.06 & $14^{\text {th }}$ \\
\hline 9. & Tailoring & 0.18 & $8^{\text {th }}$ \\
\hline 10. & Selling traditional medicine & 0.15 & $10^{\text {th }}$ \\
\hline 11. & Teaching/Civil service & 0.40 & $4^{\text {th }}$ \\
\hline 12 & Health work & 0.11 & $13^{\text {th }}$ \\
\hline 13. & Local party agent/Council member & 0.19 & $7^{\text {th }}$ \\
\hline 14. & Rental services & 0.32 & $6^{\text {th }}$ \\
\hline 15 & Hired labour & 0.55 & $2^{\text {nd }}$ \\
\hline 16 & Transportation & 0.36 & $5^{\text {th }}$ \\
\hline 17. & Construction work & 0.53 & $3^{\text {rd }}$ \\
\hline
\end{tabular}

Majority (41.70\%) of rural youth had low involvement in non-agricultural income generating activities (Table 4). According to [31] majority of rural youth in India belong to households that are self-employed in agriculture. It could be said that rural youth had medium to low involvement in non-farm income generating activities.

Table 4. Categorization of respondents according to extent of involvement in non-farm income generating activities

\begin{tabular}{|l|c|c|}
\hline \multicolumn{1}{|c|}{ Categories } & Frequencies & Percentages \\
\hline Low $<(\mathrm{X}-0.425 \mathrm{SD})$ & 103 & 41.70 \\
\hline Medium $(\mathrm{X} \pm 0.425 \mathrm{SD})$ & 96 & 38.87 \\
\hline High $>(\mathrm{X}+0.425 \mathrm{SD})$ & 48 & 19.43 \\
\hline Total & 247 & 100.00 \\
\hline
\end{tabular}

Mean = 4.11 Standard deviation $=3.680$.

The results of relationship between psychological characteristics and non-farm income generating activities among rural youth as shown in Table 5 revealed that rural youth's achievement motivation had significant and positive relationship with their involvement in non-farm income generating activities. The greater the rural youth desire for excellence and accomplishment, the higher were their involvement in non-farm income generating activities. Achieving ones desire in life begins with being motivated which is translated to action, which is, being involved. In the case of non-farm income generating activities, involvement could be in forms of increased time devoted to a particular non-farm income generating activities and increased number of non-farm income generating activities. It was also found that the correlation between risk orientation of rural youth and their involvement in non-farm income generating activities was significantly positive. This could mean that rural youth who were more courageous in facing risk and uncertainty participated more in non-farm income generating activities. In related findings, [32] reported that risk orientation had positive and significant relationship with livelihood security of rehabilitant farmers. In addition, it was observed that economic motivation of rural youth was significantly and positively related to their involvement in non-agricultural income generating activities. The import 
of this finding is that rural youth who placed more importance on the achievement of economic ends were more involved in non-agricultural income generating activities. Invariably, this could mean that rural youth who were involved in non-agricultural income generating activities were successful in maximizing profits and income. According to [33], a significant positive relationship exists between economic motivation of trained farm youth and their level of economic performance. Innovativeness had significant positive relationship with rural youth's involvement in non-farm income generating activities. As innovativeness of rural youth improved, their involvement in non-farm income generating activities increased. To be unique and above edge in any human endeavour, innovativeness undoubtedly becomes a sine qua non as it gives room for creativity and improvement. It could mean that innovativeness increases enthusiasm, zeal and motivation to do more as success is almost guaranteed.

Table 5. Relationship between psychological characteristics and nonfarm income generating activities

\begin{tabular}{|l|l|c|}
\hline S.No. & Psychological characteristics & PPMC Cofficients \\
\hline & & $0.455^{* *}$ \\
\hline $\mathrm{X}_{2}$. & Risk orientation & $0.364^{* *}$ \\
\hline $\mathrm{X}_{3} \cdot$ & Economic motivation & $0.446^{* *}$ \\
\hline $\mathrm{X}_{4} \cdot$ & Innovativeness & $0.345^{* *}$ \\
\hline $\mathrm{X}_{5}$. & Educational aspiration & $-0.222^{* *}$ \\
\hline $\mathrm{X}_{6}$. & Occupational aspiration & $-0.133^{*}$ \\
\hline $\mathrm{X}_{7 .}$ & Conservatism liberalism & $-0.407^{* *}$ \\
\hline $\mathrm{X}_{8}$. & Fatalism - scienticism & $-0.327^{* *}$ \\
\hline
\end{tabular}

NS = Not significant

* Significant at 0.05 level (2 - tailed)

** Significant at 0.01 level (2 - tailed).

Furthermore, the results of correlation analysis indicates that educational aspiration of respondents had significant and negative relationship with their involvement in non-farm income generating activities. This could almost be interpreted that rural youth who aspired higher education were less involved in non-farm income generating activities. There is a strong likelihood that rural youth who aspire higher education would likely be involved in highly specialized and remunerative non-farm income generating activities. Dated findings by [34] concluded that educational aspiration had a significant positive relationship with socio-economic status. Occupational aspiration had significant negative relationship with respondents' involvement in non-farm income generating activities. As occupational aspiration of rural youth moved away from farming towards factory work, office work and business in that order, there was declined involvement in non-farm income generating activities. It could be argued that rural youth who aspire sedentary type of occupation would be less involved in non-farm income generating activities ceteris paribus. There was a significant negative correlation between conservatism-liberalism of rural youth and their involvement in non-farm income generating activities. As conservatism increased, there was decreased involvement of rural youth in non-farm income generating activities as against increased involvement among liberal rural youth. According to [35], conservatives tend to be risk-averse and poorly endowed with creative ability while liberals tend to have strong appetites for risk and are more creative. Lastly, fatalism-scienticism had a significant negative relationship with respondents' involvement in non-farm income generating activities. Increased fatalism among the respondents led to their decreased involvement in non-farm income generating activities while increased scienticism resulted in their increased involvement in nonfarm income generating activities. This is because fatalistic rural youth believed that everything that happened to them was an act of god and there was nothing they could do to change it. They therefore resigned to fate and could not push further to change their lives. As a result, they were less involved in non-farm income generating activities contrary to those with attitude of scienticism.

The inter-correlations of psychological characteristics in Table 6 indicates that achievement motivation $\left(\mathrm{X}_{1}\right)$, risk orientation $\left(\mathrm{X}_{2}\right)$, economic motivation $\left(\mathrm{X}_{3}\right)$ and innovativeness $\left(\mathrm{X}_{4}\right)$ had positive and significant interrelationships with one another at 1 percent significant level. Expectedly, as economic motivation increased among rural youth, they were highly motivated to achieve, which propelled them to take risk and devise ways to accomplish their desires. Educational aspiration $\left(\mathrm{X}_{5}\right)$ was found to have significant negative relationship with economic motivation $\left(\mathrm{X}_{2}\right)$. This implies that the higher the rural youth aspired higher degrees, the lower their economic motivation and the possible explanation could be that there may be other reasons for educational aspiration other than economic gains. The other reasons could be for prestige, respect, recognition, intellectual endowment inter alia. Also, educational aspiration was positively correlated with occupational aspiration. Increased aspiration for higher education among respondents resulted to a shift away from farming towards factory work, office work and business in that sequence. The reason for the shift could be the requirement of basic literacy and numeracy skills needed to be successful in these occupations and these skills can be acquired from formal educational settings.

Table 6. Inter correlation matrix of psychological characteristics

\begin{tabular}{|c|c|c|c|c|c|c|c|c|}
\hline \multicolumn{9}{|c|}{ ycnoiogical cnaracteris } \\
\hline Psychological characteristics & $X_{1}$ & $\mathbf{X}_{2}$ & $\mathbf{X}_{3}$ & $\mathrm{X}_{4}$ & $\mathrm{X}_{5}$ & $X_{6}$ & $\mathbf{X}_{7}$ & $\mathrm{X}_{8}$ \\
\hline Achievement motivation $\mathrm{X}_{1}$ & 1 & & & & & & & \\
\hline Risk orientation $\mathrm{X}_{2}$ & $* 0.593$ & 1 & & & & & & \\
\hline Economic motivation $\mathrm{X}_{3}$ & $* * 0.259$ & $* * 0.649$ & 1 & & & & & \\
\hline Innovativeness $\mathrm{X}_{4}$ & $* * 0.359$ & $* * 0.496$ & $* * 0.615$ & 1 & & & & \\
\hline Educational aspiration $\mathrm{X}_{5}$ & -0.117 & -0.110 & $*_{-} *_{-0.250}$ & -0.066 & 1 & & & \\
\hline Occupational aspiration $\mathrm{X}_{6}$ & $* *_{-0.250}$ & $* *_{-0.206}$ & -0.068 & 0.004 & $* * 0.210$ & 1 & & \\
\hline Conservatism- liberalism $\mathrm{X}_{7}$ & $* *_{-0.319}$ & $* *_{-0.549}$ & $* *_{-0.522}$ & $* *_{-0.605}$ & 0.025 & $* 0.160$ & 1 & \\
\hline Fatalism - scienticism $\mathrm{X}_{8}$ & $* *_{-0.210}$ & $* *-0.270$ & $* *_{-0.413}$ & $* *_{-} 0.335$ & -0.038 & $* 0.139$ & $* * 0.425$ & 1 \\
\hline
\end{tabular}

NS = Not significant

* Significant at 0.05 level ( 2 - tailed)

** Significant at 0.01 level ( 2 - tailed). 
Occupational aspiration had significant negative relationships with achievement motivation and risk orientation. Rural youth who aspired occupation away from farming towards paid job were found to have low achievement motivation as well as risk orientation and accordingly could prefer a conventional ways of living other than desiring higher achievement which could involve taking risk. This could explain why occupational aspiration had significant positive correlation with conservatism-liberalism and fatalism-scienticism. Concomitantly, conservatismliberalism and fatalism-scienticism had significant negative relationships with achievement motivation, economic motivation, risk orientation and innovativeness. The tenable explanation of the relationships could be that conservative and fatalistic rural youth had lower achievement motivation, risk orientation, economic motivation and innovativeness, while liberal and scientific respondents had higher achievement motivation, risk orientation, economic motivation and innovativeness. Finally, conservatismliberalism had a significant positive correlation with fatalism-scienticism. As fatalism increased among rural youth, their conservatism also increased. Conversely, as scienticism increased among them (rural youth), they became more liberal.

\section{Conclusion and Recommendation}

It is evident from the study that rural youth in Jabalpur district of Madhya Pradesh, India were involved in a number of non-farm income generating activities. The study established relationship between involvement in non-farm income generating activities and psychological characteristics of respondents. Variables such as achievement motivation, risk orientation, economic motivation and innovativeness were positively related to involvement in non-farm income generating activities while educational aspiration, occupational aspiration, conservatism-liberalism and fatalism-scienticism were negatively related to involvement in non-farm income generating activities. While the inter correlations among achievement motivation, risk orientation, economic motivation and innovativeness were found to be significantly positive, however, the inter correlation between achievement motivation, risk orientation, economic motivation, innovativeness and conservatism-liberalism as well as fatalism-scienticism was found to be significantly negative. The implication of the findings of this study points to the fact that psychological factors to a great extent determine youth's participation in non-farm income generating activities. Therefore, development agencies, in both the public and private sectors, who are working on issues concerning rural youth in the study area, should give proper emphasis to the selected variables of the present study before launching any new program relating to their improvement through non-farm income activities. Skilled development of rural youth through intensive training and utilization of this skilled manpower in different non-income generating activities is also advocated.

\section{Statement of Competing Interest}

The author has no competing interest.

\section{References}

[1] Sheheli S, Improving Livelihood of Rural Women through Income Generating Activities in Bangladesh: PhD Dissertation 2012, Humboldt University, Berlin Germany.

[2] IFAD, The Challenge of Ending Rural Poverty. Oxford: Oxford University Press for IFAD, Rome. Rural Poverty Report 2001

[3] United Nations, World Youth Report. New York. www.un.org. 2007

[4] ILO, Global employment trends for youth. Geneva. www.ilo.org. 2004.

[5] Waldie K, Youth and Rural Livelihoods 2004. Retrieved from file: ///c:/Documents\% 20 and \% 20 settings/library/Desktop/youthan... on 21st March 2011.

[6] World Bank, Reaching the Rural Poor: A Renewed Strategy for Rural Development. Washington, DC: The World Bank. 2003.

[7] Lanjouw, J O and Lanjouw P, The Rural Non-Farm Sector: Issues and Evidence from Developing Countries. Agricultural Economics, 26(1): 1-23. 2001.

[8] Meludu N T, Ifie I, Akinbile L A and Adekoya E A, The Role of Women in Sustainable Food Security in Nigeria: A Case of Udu local Government Area of Delta State. Journal of Sustainable Agriculture, 15(1): 87-97. 1999.

[9] Reardon T, Using Evidence of Household Income Diversification to Inform Study of the Rural Nonfarm Labor Market in Africa. World Development, 25(5): 735-748. 1997.

[10] Davis J, The Rural Non-Farm Economy, Livelihoods and their Diversification: Issues and Options 2004. Chatham, UK: Natural Resource Institute.

[11] Mukherjee A N, Farm Productivity and Nonfarm Employment for Rural Development in India, PhD Thesis 2002 in Economics, University of Tsukuba.

[12] Hiremath B N, The Changing Faces of Rural Livelihood in India, In National Civil Society Conference: what it takes to eradicate poverty, held at institute of Rural Management Anand 4-6 December, 2007.

[13] CTA, A Reader: Briefing no 19-Youth and Rural Development in ACP Countries. Brussels. 2010.

[14] Micevska M and Rahut, D B, Rural Nonfarm Employment and Incomes in the Himilayas. Working Paper No. 205. New Dehli: Indian Council for Research on International Development. 2008.

[15] ReardonT, Stamoulis k, Cruz M E, Balisacan A, Berdeque J and Banks B, Rural Non-Farm Income in Developing Countries; In FAO: The State of Food and Agriculture (FAO Agriculture Series No:31) Rome. 1998.

[16] Ahmed N, The Sustainable Livelihoods Approach to the Development of Fish Farming in Rural Bangladesh. Journal of International Farm Management, 4(4): 1-18. 2009.

[17] Al-amin S, Role of Women in Maintaining Sustainable Livelihoods of Char Landers in Selected Areas of Jamalpur District. PhD Thesis, 2008 in Department of Agricultural Extension Education Bangladesh Agricultural University, Mymensingh.

[18] Ahmed N, The Sustainable Livelihoods Approach to the Development of Fish Farming in Rural Bangladesh. Journal of International Farm Management, 4(4): 1-18. 2009.

[19] Wikipedia, Jabalpur, 2013. Retrieved from http://en.wikipedia.org/wiki/jabalpur_district.

[20] Ahmed F, Siwa C and Idris N A, Contribution of Rural Women to Family Income Through Participation in Micro Credit: An Empirical Analysis, American Journal of Applied Sciences 8(3): 238-245. 2011.

[21] Ogunlade I, Adebayo S A, Socio-economic Status of Women in Rural Poultry Production in Selected Areas of Kwara State Nigeria. International Journal of Poultry Science, 8: 55-59. 2009.

[22] Ullar A K M A, Routray J K, Rural Poverty Alleviation Through NGO Interventions in Bangladesh: How far is the Achievement? International Journal of Social Economics 34(4): 237-248. 2007.

[23] Monica, B and Talukdar, T.K, Variables influencing entrepreneurship of women entrepreneurs. Indian Journal of Extension Education, 33(1\&2): 25-34.1997.

[24] Bhagyalaxmi K, Gopalkrishna R V and Sundarshan R M, Profile of the Rural Women Micro Entrepreneurs. Research Journal of Acharya N.G. Ranga Agric. Univ., Hyderabad, 31(4): 51-54. 2003.

[25] Lakshmanan K, Oliver $\mathrm{J}$ and Menon R K, Occupational preferences of nonschool going rural youth. Madras Agricultural Journal, 62 (10-12): 871-872. 1975. 
[26] Oladeji J O, Effect of Land Degradation on Income Generating Activities of Farmers in Imo State, Nigeria, Journal of Economics and Rural Development, 16(1): 93-106. 2007.

[27] Oyesola O B, Rural Dwellers Perception on Effect of Infrastructural Facilities on Livelihood Activities in Akinyele Local Government Area of Oyo State, Nigeria. Journal of Economics and Rural Development 16(1): 83-92. 2007.

[28] Okoye C U, The Rural Economy and Community Banking in Nigeria. In E C Eboh, C U Okoye \& D Ayichi (Eds.), Rural Development in Nigeria: Concepts, Processes and Prospects. Enugu: Auto-Century Publishing Company: 200-215. 1995.

[29] CPD, Nature and Impact of Women's Participation in Economic Activities in Rural Bangladesh. In Centre for Policy Dialogue (CPD) and International Rice Research Institute (IRRI) Policy Brief 7, 2004. Retrieved from http://www.cpdbangladesh.org/ publications/cpdiri/ cpdiri_7 on 11 March 2010.

[30] Ovwigho B O, Factors Influencing Involvement in Nonfarm Income Generating Activities among Local Farmers: The Case of
Ughelli South Local Government Area of Delta State, Nigeria, Sustainable agriculture Research, 3(1): 76-84. 2014.

[31] NSSO, Key Indicators of Employment and Unemployment in India, NSS 66 ${ }^{\text {th }}$ Round July 2009 - June 2010, National Sample Survey Office 2011, Ministry of Statistics and Programme Implementation, Government of India.

[32] Binkadakatti J, Analysis of Livelihood Security of Rehabilitant farmers. Ph.D Thesis 2013, University of Agricultural Sciences Dharwad Karnataka India.

[33] Renukaradhya B N, A critical study on farmers training programme in selected command areas of Karnataka state. Ph.D Thesis 1993, University of Agricultural Sciences, Bangalore.

[34] Sewell W H.and Shah V P, Social class, parental encouragement and educational aspirations. American Journal of Sociology, 77(5): 559-572. 1968

[35] Marshall A J, Vilfredo Pareto's Sociology: A Framework for Political Psychology (Rethinking Classical Sociology), 2007. Ashgate Publishing Limited Hampshire England. 